\title{
ANALYSIS OF THE IMMUNE RESPONSE IN PADEL
}

\author{
María Pía Cádiz Gallardo¹, Castellar Otín Carlos², Carrasco Páez Luis ${ }^{3}$, \\ and Pradas De La Fuente Francisco ${ }^{2}$ \\ ${ }^{1}$ Faculty of Education. University San Sebastián, Chile \\ ${ }^{2}$ Faculty of Health and Sports Sciences. University of Zaragoza, Spain \\ ${ }^{3}$ Faculty of Education Sciences. University of Sevilla, Spain
}

\section{SUMMARY}

High intensity exercise and sports activities are closely related to a general state of inflammation that can lead to immunosuppression. This physiological response could decrease sports performance and even compromise the athlete's health. The objective of this study was to investigate the acute inflammatory response of a padel match. 15 elite players $(28.2 \pm 7.9$ years $)$ participated voluntarily in the study. Different pro-inflammatory (IL-1ß, IL-2, IL-6, IL-7, IL-8, IL-12 and TNF $\alpha$ ) and antiinflammatory cytokines (IL-5, IL-10 and IL-13) were analyzed before and after a match. The results showed a decrease in IL-7 ( $p=0.007)$ and IL-8 $(p<0.03)$ and increases in IL-10 $(\mathrm{p}<0.04)$. The results obtained suggest that the practice of highlevel padel induces an anti-inflammatory response.

Key words: racket sports, inflammation, cytokines, interleukins, immunoassay.

\section{INTRODUCTION}

The performance of strenuous exercise and sports activities, of high intensity, without proper rest, etc., is closely linked to the pathogenesis of various muscle injuries and to a generalized state of inflammation (Reighlin, 1993), which in exaggerated acute phase can even lead to immunosuppression, with results and 
physiological responses that can not only decrease and significantly affect athletic performance but can even compromise the health of the athlete.

The immunosuppression generated by very stressful sports activities produces, as a more relevant consequence, an elevation of pro-inflammatory cytokines levels, such as interleukin 1 (IL-1), IL-6 and tumor necrosis factor alpha (TNF $\alpha$ ) (Cordova, Montserrat, Villa, Reyes \& Álvarez-Mon, 2006), although there are many more factors that can modify the function of the immune system (Sigal \& Ron, 1994).

Low performance, as a result of a higher than usual requirement to maintain a certain level of intensity, can be due to different causes. It could simply be a transient decrease in the working capacity of the skeletal muscle during the sporting activity itself (Asmussen, 1993), or an acute inability to maintain a certain physical performance, either by not being able to maintain the intensity of the effort (Edwards, 1981), or by a diminished capacity to generate force (Vollestad \& Sejersted, 1988) and maintain an appropriate gestural technique, for example.

This decrease in yield could be derived from an intensification of the organic response of certain immunological markers (Padilla, Cuesta \& Polo, 1997). Taking these arguments into consideration, it is easy to understand the need for and importance of controlling all those metabolic and immunological variables that may alter sports performance.

In general, intense exercise induces transitory inflammatory responses, especially in the muscles most requested to withstand some impact and stress, participating in muscle repair processes. However, the repetition of intense and acute inflammatory reactions, caused by excessive daily loads of training or several days of high competition, can provoke a chronic local inflammatory affectation that can cause muscle aches, overloads and an important decrease of the physical performance.

As a consequence, the intensity of the local inflammatory response is proportional to the muscle damage caused by sports physical activity. It is evident that excessive loads that cause muscle damage elevate the intensity of the inflammation to a degree where it can have systemic repercussions on the body of the athlete. This systemic involvement is an acute phase response to inflammation, which if intense and maintained for a period, can alter the immunological capacity of the athlete, generating immunosuppression situations that lead to an increase in susceptibility to infection, decreased performance and even put the athlete's health in risk (Pedersen, 1997).

The evidence found shows that the performance of strenuous exercise is closely related to the development of muscle injuries and a systemic state of inflammation (Reighlin, 1993). This immunosuppression is almost identical to that generated in disease states and is associated with activation, elevation and 
communication of mediators called cytokines, which can be of two types: pro and anti-inflammatory (Zuber, 2011).

At a molecular level, cytokines are proteins. Their function in the body is to coordinate the response of the immune system by recruiting or inhibiting the functions of specific cells such as neutrophils. Cytokines can be divided into several groups, depending on their activation context, the class of cells that produce them, etc. Among others, we can highlight the importance of IL (IL-1, IL-2, etc.), TNF and chemokines (IL-8) (Dinarello, 2007).

The practice of a sport, if produced at high intensities and maintained over time, causes tissue damage, especially due to repetitive micro traumas and the increase in the production of free radicals as a result of an increase in the consumption of oxygen (Leeuwenburg, Fiebig, Chndwaney \& Ji, 1994), causing an inflammatory state, with increased production of neutrophils and even proinflammatory cytokines such as IL-1, IL-6 and TNF $\alpha$ (Koning, Gratthwohl, Weinstock, Northoff \& Berg, 2000; Macintyre, Sorichter, Mair, Berg \& Mc Kenzie, 2001), cytokines closely related to inflammation and muscle damage induced by exercise, as can be seen from the data obtained in muscle biopsies (Córdova et al., 2006). Cytokines are, therefore, the basis of the immune response.

Considering the importance of the immunological markers described for the health and performance of athletes, it is of interest to evaluate and control them, since they allow a very exhaustive way to know and quantify the effort produced by a given load and its impact on the organism. In this sense, the objective of this study was to investigate the acute inflammatory response of a padel match.

\section{METHODOLOGY}

A group of high-level padel players, 15 men (28.2 \pm 7.9 years), participated voluntarily in the study. The players selected to be part of this investigation regularly disputed national, international and / or professional competitions. The show is characterized by being a very homogeneous group of athletes, with common sports objectives and similar training.

Before starting the study, the athletes were verbally informed of the objective, procedure to follow as well as the risks and benefits of their participation. All athletes signed an informed written consent. The research was approved by the Clinical Research Ethics Committee of the Department of Health and Consumption of the Government of Aragon (Spain), following the guidelines of the Declaration of Helsinki.

To perform the immunological study based on the production of pro (IL-1ß, IL2, IL-6, IL-7, IL-8, IL-12 and TNF $\alpha$ ) and anti-inflammatory cytokines (IL-5, IL-10 and IL-13), two blood samples (pre and post) of $10 \mathrm{ml}$ were taken in test tubes, 
containing 35 micro-moles of EDTA $2 \mathrm{~K}+$ and $1500 \mathrm{IU}$ of the kallikrein inactivator. The tubes were refrigerated until centrifuged at $2150 \mathrm{rpm}$ for $15 \mathrm{~min}$ at $4^{\circ} \mathrm{C}$. The plasma aliquots were separated and stored at $-80^{\circ} \mathrm{C}$. The analysis technique used was by enzyme-linked immunosorbent assay with the ELISA method.

\section{RESULTS}

The analysis of the results has been carried out using SPSS 22.0 software (IBM Corp, Armonk, United States), using descriptive, inferential and normality statistical tests to calculate means, standard deviations, and confidence intervals. First, the normality of the sample was determined through the Shapiro-Wilk test. When the normality hypothesis was not met, the nonparametric Wilcoxon test was performed as an inferential test to analyze the pre-post differences of the variables. The criterion of significance was established at $\mathrm{p}<0.05$.

Table 1. Characteristics of the sample (mean \pm standard deviation)

\begin{tabular}{lc}
\hline Variable & Men \\
\hline Age (years) & $28.2( \pm 7.9)$ \\
Body mass $(\mathrm{kg})$ & $78.2( \pm 8.5)$ \\
Height $(\mathrm{cm})$ & $178.3( \pm 4.4)$ \\
Fat mass $(\%)$ & $10.6( \pm 2.5)$ \\
Sports experience (years) & $7.3( \pm 3.3)$ \\
Weekly traininig (hours) & $8.1( \pm 0.3)$ \\
\hline
\end{tabular}

Table 2. Immunological markers analyzed (mean \pm standard deviation)

\begin{tabular}{cccc}
\hline \multicolumn{4}{c}{ PRO-IFLAMAMTORY $\left(\mathrm{pg} \cdot \mathrm{ml}^{-1}\right)$} \\
\hline Pre & Post & $p$ \\
\hline IL-1ß & $0.2( \pm 0.2)$ & $2.6( \pm 3.2)$ & 0.57 \\
IL-2 & $0.5( \pm 0.6)$ & $4.2( \pm 4.4)$ & 0.89 \\
IL-6 & $0.2( \pm 0.0)$ & $0.6( \pm 0.9)$ & 0.34 \\
IL-7 & $22.5( \pm 18.7)$ & $0.2( \pm 0.3)$ & 0.007 \\
IL-8 & $0.6( \pm 0.2)$ & $0.5( \pm 0.7)$ & 0.022 \\
IL-12 & $0.6( \pm 0.6)$ & $9.4( \pm 1.2)$ & 0.75 \\
TNF $\alpha$ & $0.7( \pm 0.1)$ & $0.9( \pm 0.5)$ & 0.34 \\
\hline \multicolumn{4}{c}{ ANTI-INFLAMMATORY $(\mathrm{pg} \cdot \mathrm{ml}-1)$} \\
\hline IL-5 & Pre & Post & \\
IL-10 & $0.5( \pm 0.3)$ & $0.7( \pm 1.2)$ & 0.57 \\
IL-13 & $2.3( \pm 2.4)$ & $202.8( \pm 27)$ & 0.03 \\
\hline
\end{tabular}




\section{DISCUSSION}

In order to observe if an organic response of inflammation existed, two cytokines, IL-8 and TNF $\alpha$, have been analyzed, both being considered as the two most relevant ones with a pro-inflammatory character (Filella, Molina \& Ballesta, 2002).

The acute TNF $\alpha$ response to a padel competition was not very significant. There was an increase above the basal levels, but only moderate, just as found in previous studies (Pedersen, 2011). The slight increase in this cytokine may be due to the duration and intensity of the competition (Scott et al., 2011), and may be related to the eccentric nature of the game actions that occur in this sport (Pradas et al., 2014). This suggests that the rise of $\mathrm{TNF} \alpha$ might be a defense measure against the stress produced by the padel competition

It has been demonstrated that intense and prolonged exercise causes changes in the immune system (Pedersen \& Hoffman-Goetz, 2000), increasing, among others, the levels of IL-8 (Nieman, 1987). This increase in pro-inflammatory cytokines has been associated with mild muscle damage.

However, the most relevant in this research has been the very significant decrease in IL-7 and IL-8. This data shows the aerobic nature of padel, with efforts of moderate intensity (Pradas et al., 2014), which do not reach high enough levels to trigger a true acute inflammatory process (Krüger \& Mooren, 2014), In fact, the situation is quite the opposite, since there is a protective effect derived from the rise of anti-inflammatory cytokines, which induces an organically stable metabolic response to this type of sport, allowing to maintain a greater sport performance to the players (Witek et al., 2016).

The anti-inflammatory cytokines studied have increased significantly (IL-10), similar to what happened in the sport of tennis (Witek et al., 2016). This is probably stimulated by muscle contraction, related as an inhibition response of TNF $\alpha$ (Tilg, Dinarello \& Mier, 1997). These results coincide with other studies in which an anti-inflammatory response is showed (Pedersen, 2011).

\section{CONCLUSIONS}

The slight increase of the pro-inflammatory cytokine TNF $\alpha$ together with the important decrease in IL-8 is a positive balance in the padel towards the antiinflammatory response of the organism during the practice of this sport.

The increase of the anti-inflammatory interleukins IL-10 and IL-13 makes it possible to affirm that the practice of padel can be considered as a healthenhancing physical activity due to its protective effect. 


\section{REFERENCES}

1. Asmussen, E. (1993). Muscle fatigue. Med Sci Sports, 25(4), 411-420.

2. Córdova, A., Montserrat, S., Villa, G., Reyes, E., \& Álvarez-Mon, M. (2006). Effects of AM3 (Inmunoferon $\AA$ ) on increased serum concentrations of interleukin- 6 and tumour necrosis factor receptors I and II in cyclists, J Sports Sci, 24(6), 565-573.

3. Dinarello, C.A. (2007). Historical review of cytokines. Eur J Immunol, 37(1), S34S45. doi:10.1002/eji.200737772.

4. Edwards, R. (1981). Human muscle function and fatigue. London: Pitman Medical.

5. Filella, X., Molina, R., \& Ballesta, A.M. (2002). Estructura y función de las citocinas. Med Integr, 39(2), 63-71.

6. Koning, D., Gratthwohl, D., Weinstock, C., Northoff, H., \& Berg, A. (2000). Upper respiratory tract infection in athetes influence of lifestyle, type of sport, training effort, and inmunostimulant intake. Exerc Immunol Rev,6, 102-120.

7. Krüger, K., \& Mooren, F.C. (2014). Exercise-induced leukocyte apoptosis. Exerc Immunol Rev, 20(20), 117-134.

8. Leeuwenburg, C., Fiebig, R., Chndwaney, R., \& Ji, L.L. (1994). Aging and exercise training in skeletal muscle: responses of glutathione and antioxidant enzyme systems. Am J Physiol, 267(2), 439-445.

9. Macintyre, D.L., Sorichter, S., Mair, J., Berg, A., \& Mc Kenzie, D.C. (2001). Markers of inflammation and myofibrillar proteins following eccentric exercise in humans. Eur J App Phyisiol, 84(3), 180-186.

10. Nieman, D.C. (1987). Immune response to heavy exertion. J Appl Physiol, 82, 1385-1394.

11. Padilla, S., Cuesta, G., \& Polo, J.M. (1997). Recuperación biomédica en la fatiga muscular. Madrid: Síntesis.

12. Pedersen, B.K. (1997). Exercise immunology. Austin: RG Landers.

13. Pedersen, B.K. (2011). Muscles and their myokines. Journal of Experimental Biology, 214(2), 337-346.

14. Pedersen, B.K., \& Hoffman-Goetz, L. (2000). Exercise and the immune system: regulation, integration, and adaptation. Physiological reviews, 80(3), 1055-1081.

15. Pradas, F., Cachón, J., Otín, D., Quintas, A., Arracó, S.I., \& Castellar, C. (2014). Análisis antropométrico, fisiológico y temporal en jugadoras de pádel de elite. Retos. Nuevas tendencias en Educación Física, Deporte y Recreación, 25, 107-112.

16. Reighlin, S. (1993). Neuroendocrine-immune interactions. New Engl J Med, 329, 1246-1253.

17. Scott, J.P., Sale, C., Greeves, J.P., Casey, A., Dutton, J., \& Fraser, W.D. (2011). Effect of exercise intensity on the cytokine response to an acute bout of running. Med Sci Sports Exerc, 43(12), 2297-2306.

18. Sigal, L.H., \& Ron, Y. (1994). Immunology and inflamation. Basic mechanisms and clinical consequences. New York: McGraw-Hill.

19. Tilg, H., Dinarello, C.A. \& Mier, J.W. (1997). IL-6 and apps: anti-inflamatory and immunosupressive mediators. Immunlogy today, 18(9), 428-432.

20. Witek, K., Gurek, P., Zmijewski, P., Jaworska, J., Lipinska, P., Dzedzej-Gmiat, A., Antosiewicz, J., \& Ziemann, E. (2016). Myokines in Response to a Tournament Season among Young Tennis Players. BioMed Research International, 2016, 1-7. 
21. Zuber, P. (2011). Cytokines and their physiologic and pharmacologic functions in inflammation: a review. Int. J. of Pharm. \& Life Sci, 2(11), 1247-1263.

\section{АНАЛИЗ ИММУННОГО ОТВЕТА В ПАДЕЛЕ}

\section{АННОТАЦИЯ}

Высокоинтенсивные физические нагрузки и занятия спортом тесно связаны с общим состоянием воспаления, которое может привести к иммуносупрессии. Такая физиологическая реакция может снизить спортивные результаты и даже поставить под угрозу здоровье спортсмена. Целью данного исследования было изучить острый воспалительный ответ на матч по паделю. В исследовании добровольно приняли участие 15 элитных игроков $(28,2 \pm 7,9$ лет). Различные провоспалительные (IL-1ß, IL-2, IL-6, IL-7, IL-8, IL-12 и TNF $\alpha$ ) и противовоспалительные цитокины (IL-5, IL-10 и IL-13) были проанализированы до и после матча. Результаты показали снижение IL7 (p=0,007) и IL-8 (p<0,03) и повышение IL-10 (p<0,04). Полученные результаты свидетельствуют о том, что занятия паделем на высоком уровне вызывают противовоспалительный ответ.

Ключевые слова: спорт с ракетками, воспаление, цитокины, интерлейкины, иммуноферментный анализ. 